\title{
Effects of Sugars on in vitro Culture of Bauhinia purpurea $\mathrm{L}$.
}

\author{
Belai Meeta Singh \\ Patan Multiple Campus, Tribhuvan University, Lalitpur, Nepal \\ e-mail: belaisingh@gmail.com
}

\begin{abstract}
Bauhinia purpurea L. is a moderate sized tree with multipurpose value. It is distributed in sub-Himalayan tracts. propagation of this plant was tested on different sugars, maltose, sucrose, glucose, galactose, lactose and fructose each with MS medium. Multiplication rate of plants were recorded after 8 weeks of culture. Sucrose produced 2.20 nodes and $10.05 \mathrm{~mm}$ shoot length the other sugars did not induce shoot length elongation and node developments.
\end{abstract}

Key words: micropropagation, nodal explants, Maltose, sucrose, glucose, galactose, lactose and fructose.

\section{Introduction}

Bauhinia purpurea $\mathrm{L}$. is a leguminous plant of moderate sized possessing ornamental and fodder value. It is distributed in sub-Himalayan tracts. It has been cultivated in the plain regions up to the elevation of $1350 \mathrm{~m}$. The tree also yields gum and the ethnobotanical reports made by Manandhar (2000) showed that its fruits are cooked and also pickle. The wood is used for agricultural implements and is suitable for scanting and rafters in inferior construction work. The long flat pods are best until February or March. Pettit et al. (2006) have isolated new and very remarkable (dibenzan L b, floxipens) cancer cell growth inhibitors and have designated them as Bauhiniastatins 1-4. Upon evaluation of anticancer activity Bauhiniastatins 1 exhibited significant growth inhibition of P 388 cancer cell line.

Micropropagation of Bauhinia purpurea L. has successfully been developed by Kumar (1992) using Murashige and Skoog (1962) (MS) medium with 5.0 $\mu \mathrm{M}$ kinetin. Similarly, in vitro regeneration of $B$. vahlii has been developed by Dhar and Upreti (1999) using MS medium supplemented with $2.5 \mu \mathrm{M}$ kinetin plus $100 \mathrm{mg} / \mathrm{l}$ adenine sulphate. Murthur and Mukunthakumar (1992) developed in vitro propagation protocols for two leguminous trees, $B$. variegata and Parkinsonia aculeata from nodal explants of mature trees using MS medium with 13.3 $\mu \mathrm{M}$ and 8,9 $\mu \mathrm{M}$ BAP respectively. Shukla et al. (2010) observed maximum multiple shoots on MS medium supplemented with $1.0 \mathrm{mg} / 1$ kinetin from nodal explants of Withania somnifera. Whereas Pant and Swar (2011) carried out micropropagation of Cymbidium iriodoides on MS medium supplemented with $1.0 \mathrm{mg} / \mathrm{l} \mathrm{BAP}$ and $1.0 \mathrm{mg} / \mathrm{l} \mathrm{NAA}$ was found best for germination. Here, the experiments are mainly emphasized for the sugar test.

\section{Methodology}

The seeds of B. purpurea were procured from district Aforestation Division, Hattisar, Kathmandu, Nepal and were carried to the Institute of Pharmacognosy, Vienna, Austria and were preserved at $4^{\circ} \mathrm{C}$ refrigerator until experimental use. The healthy seeds were washed with few drops of Teepol detergent solution. They were soaked in distilled water for an hour prior to sterilization. The soaked seeds were washed with distilled water for 5 times and sterilized with $10 \%$ sodium hypochlorite solution for 10 minutes and removed the traces of sodium hypoclorite by washing thoroughly with sterilized distilled water five times inside laminar flow hood chamber. Finally the seeds were again sterilized in $70 \%$ alcohol for one minute and washed with sterilized distilled water for 5 times to remove the alcohol. The seeds 
were inoculated on $8 \%$ (bacteriological) agar medium containing $3 \%$ sucrose and the $\mathrm{pH}$ was adjusted to 5.8 before autoclaving and then sterilized at $15 \mathrm{lb}$. / sq. inch pressure for 15 minutes in autoclave. Cultures were maintained in the culture room at $25^{\circ} \mathrm{C}\left( \pm 2^{\circ} \mathrm{C}\right)$. Cool white fluorescent light of an intensity of approx. $40 \mu$ mol.m- ${ }^{-2} \mathrm{~s}^{-1}$ was supplied through OSRAM BIOLUX tubes at a 16 hr light period. Nodal explants obtained from germinated seedlings were cultured on MS medium containing $0.5 \mu \mathrm{M}$ BAP produced multiple shoots which were used for experimental purposes. Maltose, sucrose, glucose, galactose, lactose and fructose each with $30 \mathrm{mg} / \mathrm{l}$ was augmented with MS medium.

The nodal explants obtained from MS medium $0.5 \mu \mathrm{M}$ BAP were cut into $2 \mathrm{~cm}$ pieces and were placed on MS medium each with different sugars in baby food jar $200 \mathrm{ml}$ capacity with $40 \mathrm{ml}$ medium. In each of the vessels 4 explants were inoculated. All the results obtained were worked out statistically with SPSS, a system of analytical procedure.

\section{Results and Discussion}

Most of the sugars in the culture of nodal explants showed poor response of nodal multiplication ion and shoot length elongation. On MS medium supplemented with maltose produced 1.55 nodes and $9.0 \mathrm{~mm}$ shoot length elongation. In presence of sucrose produced 2.20 nodes and $10.05 \mathrm{~mm}$ shoot length was formed. Whereas, glucose, galactose, lactose and fructose did not induce shoot length elongation and node developments (Fig.1, 2). All the sugars except maltose did not lead to the formation of calli. The nodal explants grown on MS with glucose, galactose, lactose and fructose could not response well. The explants turned yellow after two weeks of culture (Table 1).

Table 1. Effects of sugars in Bauhinia purpurea

\begin{tabular}{l|c|c|c}
\hline $\begin{array}{c}\text { Treatments/ Media } \\
(\mu \mathrm{M})\end{array}$ & $\begin{array}{c}\text { Number of Nodes/culture } \\
\text { Mean } \pm \mathrm{SE}\end{array}$ & $\begin{array}{c}\text { Shoot length(mm) } \\
\text { Mean } \pm \text { SE }\end{array}$ & $\begin{array}{c}\text { Q Calli (mm) } \\
\text { Mean } \pm \text { SE }\end{array}$ \\
\hline Sugars $(30 \mathrm{mg} / \mathrm{l})$ & & & \\
Maltose & $1.55 \pm 0.1$ & $9.00 \pm 0.9$ & $0.25 \pm 0.25$ \\
Sucrose & $2.20 \pm 0.2$ & $10.05 \pm 0.8$ & $0.00 \pm 0.0$ \\
Glucose & $1.25 \pm 0.1$ & $6.75 \pm 0.5$ & $0.00 \pm 0.0$ \\
Galactose & $1.25 \pm 0.2$ & $7.55 \pm 0.5$ & $0.00 \pm 0.0$ \\
Lactose & $1.00 \pm 0.0$ & $5.30 \pm 0.6$ & $0.00 \pm 0.0$ \\
Fructose & $1.00 \pm 0.0$ & $6.90 \pm 0.5$ & $0.00 \pm 0.0$ \\
\hline
\end{tabular}

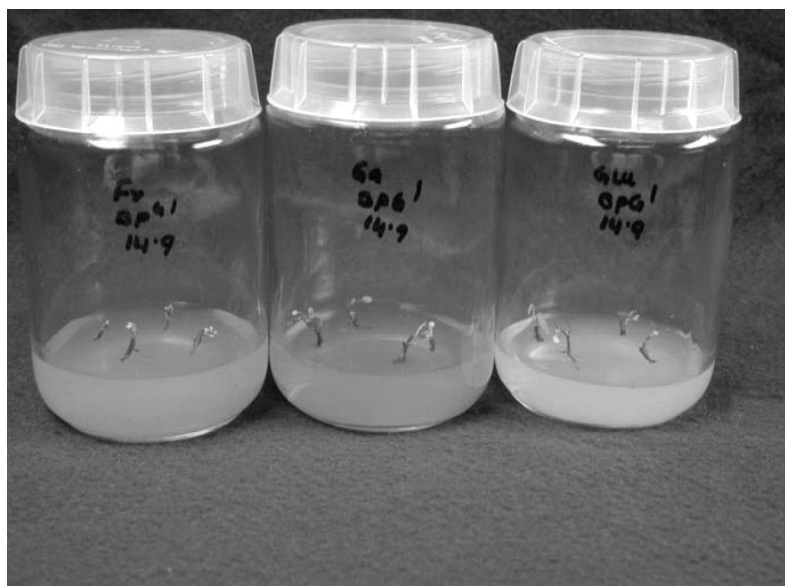

Fig.1. Plants growing on fructose, galactose and glucose

Relatively few scientists have tested different sugars. The effect of sugars on B. purpurea was apparently seen that sucrose was found the most effective followed by maltose, glucose, galactose, lactose and fructose.

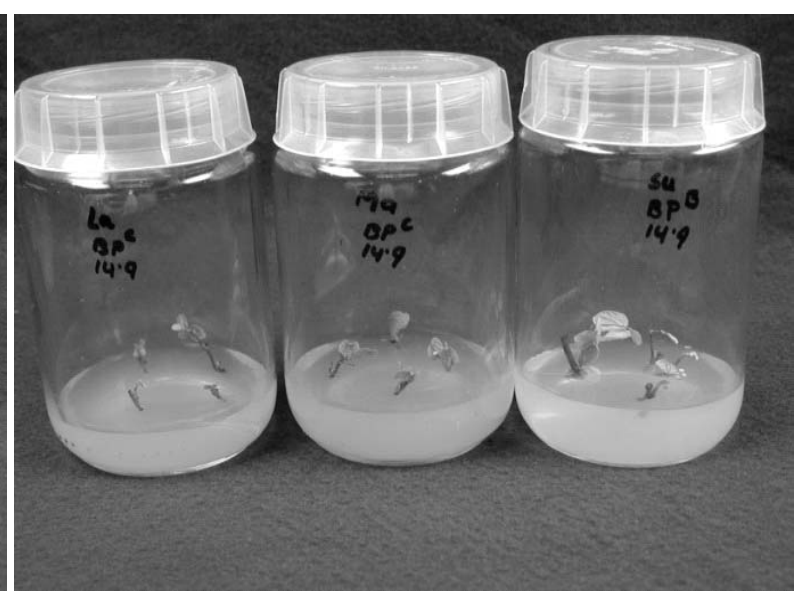

Fig.2. Plants growing on lactose, maltose and sucrose

Mataui (1998) found fructose, galactose and sucrose to be callogenesis sugars, whereas maltose, lactose and galctose were found less callus stimulatory sugars. In present experiment only maltose showed few calli 
Belai Meeta Singh/Effects of Sugars on in......

formations. Premkumar et al. (2011) developed a protocol for micropropagation of Scoparia dulcis L. on MS medium supplemented with $22.32 \mu \mathrm{M} \mathrm{KI}$ and $4.44 \mu \mathrm{M}$ BAP. Goyal et al. (1984) found sucrose was the best among all the carbohydrates tested for proliferations and elongation of shoots on Prosopis cineraria L. So, present work also corroborates with them.

\section{Acknowledgements}

Prof. Dr. Brigitte Kopp and Dr. Cristoph Wawrosch of Institute of Pharmacognosy, University of Vienna and Prof. Dr. Sanu Devi Joshi, Tribhuvan University are duely acknowledged for providing necessary supports. The Austrian Academic Exchange Service (ÖAD), Vienna Austria is also acknowledged for financial support.

\section{References}

Dhar, U. and J. Upreti. 1999. In vitro regeneration of a leguminous liana (Bauhinia vahlii Wight and Arnott). Plant Cell Reports 18:664-669.

Goyal, Y. and H. C. Arya. 1984. Tissue Culture of desert trees: 1. Clonal multiplication of Prosopis cineraria by Bud culture. J. Plant Physiol. 115:183-189.

Kumar, A. 1992. Micropropagation of a mature leguminous tree- Bauhinia purpurea. Plant Cell Tissue and Organ Culture 31:257-259.

Maataoui, E.L.M., H. Espagnac, B. Jaber and A. Lopez. 1998. Regulation of in vitro callogenesis and organogenesis from Albizia root explants by carbohydrate source modifications. Journals of Plant Physiology 152:494-501.

Manandhar, N.P. 2002. Plant and people of Nepal. 106. Timber Press, INC. The Haseltine Building, 133 S.W. Second Avenue, Suit 450. Portland, Oregon, 97204, U.S.A.

Mathur, J. and S. Mukunthakumar. 1992. Micropropagation of Bauhinia variegata and Parkinsonia aculeata from nodal explants of mature trees. Plant Cell Tissue and Organ Culture 28:119-121

Murashige, T. and F. Skoog. 1962. A revised medium for rapid growth and bioassays with tobacco tissue cultures. Physiol. Plant. 15:473-497.

Pant, B. and S. Swar 2011. Micropropagation of Cymbidium iriodoides. Nepal Journal of Science and Technology. 12: 91-96.

Pettit, G. R., A. Numata, C. Jwamoto , M. Usami, T. Yamada , H. Oshishi and G. M. Cragy 2006. Antineoplastic agents, isolation and structure of Bauhinastatins 1-4 from Bauhinia purpurea. J. Nat. Prod. 69:323-327.

Premkumar, G., R. Shankaranarayan, S. Jeeva and K. Rajarathiram, 2011. Cytokinin induced shoot regeneration and flowering of Scoparia dulcis L. (Scrophularaceae) an ethnomedicinal herb. Asian Pacific Journal of Tropical Biomedicine 11:169172.

Shukla, D.D., N. Bhattarai and B. Pant. 2010. In vitro mass propagation of Withania somnifera L. Dunal. Nepal Journal of Science and Technology 11: 101-106. 
Nepal Journal of Science and Technology Vol. 15, No.2 (2014) 47-50 